\title{
Europe and its entangled colonial pasts
}

\author{
Europeanizing the 'imperial turn'।
}

\section{Elizabeth Buettner}

Coming to terms with the long-term impact of empires and decolonizations and selectively (however reluctantly) grappling with their diverse histories and legacies count as widely shared experiences in many European countries in recent decades. Since the 1990s, a growing number of historians and academics in related disciplines have illuminated the wide variety of ways Europe and other parts of the world have 'entangled histories', or histoires croisées (Werner and Zimmermann 2006). From the early modern era onwards and gathering particular momentum in the late nineteenth century, Europe's evolution became increasingly intertwined with far-flung transoceanic regions as maritime empires expanded and transformed. 'Home' and 'away' were mutually constituted arenas, scholars insisted, not hermetically sealed separate spheres; Europe itself thereby became transformed through unequal geopolitical power relations, an increasingly globalized economy, and mobile peoples and cultures (Stoler and Cooper 1997). Global flows of people (whether enslaved, indentured, or voluntary), goods, capital, and ideologies linked European colonizing countries with overseas possessions and spheres of influence during an extended age of empire. Today, these complex colonial legacies and heritage remain central not only to postcolonial societies overseas but also still echo resoundingly across Europe itself.

Britain, France, Portugal, and other Western and Southern European examples remain the most familiar cases within the 'imperial turn' now taken by many scholars (Buettner 2016), but this chapter insists on positioning empires and colonialism as defining characteristics of a far wider European history, not simply that of a series of individual nations. Albeit in very different and inevitably uneven ways, Europe's centuries-long history of empires extended to Scandinavia together with Central and Eastern Europe, including during and after the state-socialist era. Europe has been historically forged by maritime as well as continental land empires (including the Habsburg empire, imperial and then Nazi Germany, and Tsarist Russia followed by the Soviet Union). As such, forms of colonialism not only extended outwards to the Americas, Africa, Asia, and Australasia but also across the Global North and inwards in the form of 'internal colonialisms'. Seas and oceans separating imperial centres from far-off colonies, in sum, were not an 
inevitable requirement, either for empire or for colonial-style practices and relationships (Etkind 2011, 5).

Whether maritime, terrestrial, or indeed both, empires remained the dominant form many European polities took until well into the twentieth century - in Jürgen Osterhammel's words, well past the 'so-called age of nation-states' that has conventionally described the nineteenth century (Osterhammel 2014, 88-9). 'Empires can be nations writ large', as Krishan Kumar has put it, and 'nations empires under another name' (Kumar 2017, 23). Benedict Anderson's account of 'official nationalisms' similarly stresses how these could involve 'stretching the short, tight skin of the nation over the gigantic body of the empire' (as exemplified by the British empire or the Portuguese empire) (Anderson 2006, 86, 140).

Although the pages that follow can only scratch the surface of what is, by now, an immense and ever-evolving research field, they chart the inseparability of countless national/imperial and continental/global dynamics, briefly noting some better-known examples as well as pausing to take account of cases that remain less commonly viewed through imperial lenses outside specialist academic circles. Viewing forms of empire and colonialism located within and beyond Europe as candidates for comparative treatment and potential cross-fertilization rather than splendid isolation allows empire to be examined as a common European heritage, defining the continent and the wider world (Burbank and Cooper 2010; Leonhard 2016). If 'Europeanization' can be understood as 'a variety of political, social, economic and cultural processes that promote (or modify) a sustainable strengthening of intraEuropean connections and similarities through acts of emulation, exchange and entanglement and that have been experienced and labelled as "European", to adopt Ulrike von Hirschhausen and Kiran Klaus Patel's encapsulation, then colonialism demands to be placed far more firmly within this rubric than has typically been the case (Von Hirschhausen and Patel 2010, 2). 'Europeanizing' colonialism, and ultimately decolonization, as both a transnational European (indeed, pan-European) and global heritage, moreover, also extends to recognizing their place in Europe's integration process since the late 1950s, a theme this chapter broaches in its conclusion.

\section{Paving the way: approaching Western and Southern Europe's overseas histories}

Since 'discovering' the New World across the Atlantic and ultimately circumnavigating the globe from the end of the fifteenth century, European states built upon pre-existing trans-Mediterranean engagements and nascent links with the west coast of Africa to carve out increasingly global forms of presence and power. Ocean-spanning realms presided over by Spain, Portugal, the Netherlands, Britain, and France expanded, contracted, changed hands, and increased once more across the Americas, Caribbean, Asia and the Pacific region, and along Africa's coasts before moving ever further inland as 
more and more European countries competed in their 'Scramble for Africa' as the nineteenth century drew to a close. Imperial expansionism became integral to the very fabric of nation-states and to dominant conceptions of their identity and heritage. The pioneering roles of Spain and Portugal in the 'Age of Discoveries' featuring renowned seafarers like Columbus, Da Gama, and Magellan took their place alongside the Netherlands' global engagements integral to the Dutch seventeenth-century 'Golden Age' (Bethencourt and Curto 2007; Subrahmanyam 2007; Weststeijn 2014). Britain's and France's expansionism also gained momentum, ultimately rendering theirs the world's two largest empires in the late nineteenth and early twentieth centuries.

Influenced by postcolonial studies (much of it spearheaded by literary scholars) and anthropology, historians gradually united what had long been distinct fields of academic work, bringing overseas empires within the fold of domestic European histories. Just as Anglophone scholars were long at the vanguard of postcolonial studies, so too were historians of Britain and the British empire prominent in the early stages of mapping what ultimately became widely known as the 'new imperial history' (Burton 2003; Hall and Rose 2006; Kennedy 2018; MacKenzie 1986; Ward 2001; Wilson 2004). Britain-focused work long remained strongly represented (particularly focused on its 'jewel in the crown' in India, settler colonies, and the West Indies), even as Portugal's entanglements with Brazil and Africa, France's with its vast empire, and the Dutch presence in and beyond the East and West Indies became the subjects of new research approaches (Koekkoek et al. 2017; Raben 2013). Not only was Britain's history explored as inseparable from that of its empire (and later the Commonwealth) and France's from la plus grande France ('Greater France') beyond the seas: empires were equally important (and perhaps more so) to smaller and less powerful nations on the international stage (Blanchard et al. 2008; Conklin et al. 2011; Stovall 2015; Wilder 2003). By virtue of overseas possessions, Portugal could claim to be much more than a diminutive, poor, and peripheral European country, while possessing Congo allowed Belgium the pretensions of being la plus grande Belgique (Goddeeris 2015; Goddeeris et al. 2020; Sanches 2006; Santos 2002; Sidaway and Power 2005; Viaene et al. 2009).

Colonial latecomers included Germany and Italy, which looked overseas as a means of consolidating their standing as newly unified nation-states by adopting behaviours characteristic of Great Powers. For state- and privatesector imperial enthusiasts, gaining footholds in Asia and particularly Africa meant winning their rightful 'place in the sun', whether in Germany's African or Pacific territories or the northern African lands claimed by Italy that led Mussolini to fantasize about the Mediterranean's possibilities as an 'Italian lake'. Overseas empires were thus explored as constitutive features of the political, economic, social, and cultural orders of European countries, whether they counted as long-established leading players or more recent arrivals on the international scene (Borutta and Gekas 2012; MacKenzie 
2011; Pergher 2017; for introductions to a now-voluminous and ever-expanding body of work, see Buettner 2016, 1-19; Lombardi-Diop and Romeo 2015a, 2015b; Schilling 2015; Thomas and Thompson 2018).

So integral was empire-building that the distinction between national and imperial territories and histories often proved difficult to draw. Scholars have long debated whether Ireland was subjected to England's internal colonialism that preceded and continued alongside Britain's expansionism across the globe (Hechter 1978; Howe 2000; Kenny 2004; McDonough 2005). Viewing Ireland's past - as well as Northern Ireland's experiences after it stayed part of the United Kingdom after Ireland's 1921 partition - through the lens of postcolonial studies has generated accounts of its subjugation through settler colonialism and heavy-handed rule from London, with Catholic Irish seen as racially inferior and undeserving of sovereignty in a manner that bore resemblance to Britain's (and other Western countries') stance towards Africans, Asians, and other colonial subjects (Bruendel 2017; Laird 2015). By the same token, however, many Irish (alongside Scots) had long featured prominently in Britain's collective imperial activities further afield, rendering Ireland simultaneously colonized at home yet colonizing overseas (MacKenzie and Devine 2011). Algeria under French rule provides a different example. Until forced out in 1962, France insisted that Algeria was not a colony but rather three départements of the nation itself, despite being situated across the Mediterranean as opposed to directly adjacent within Europe (Shepard 2006; Stora 1991). Portugal adopted a similar stance, with its dictatorship ultimately redefining colonies in Africa and Asia as 'overseas provinces' in 1951 (Jerónimo and Pinto 2013).

These cases illustrate the durability of European imperial agendas emphasizing bonds with overseas possessions well after the Second World War, a watershed conventionally understood as heralding the onset of widescale global decolonization. Some European overseas empires like Germany's had already ended, while the 1940s did indeed bring independence to India, Indonesia, and a handful of other territories. In countless settings, however, Western and Southern European powers sought to hold tightly onto their remaining empires in a Cold War world dominated by the United States and the Soviet Union, fighting anti-colonial insurgencies and other proliferating nationalist movements by insisting on national-imperial connectedness. Britain's persistent attachment to the Commonwealth that evolved out of empire, France's post-war relabelling of its empire as the French Union (and, like Portugal, designating many colonies as 'overseas departments and territories'), and the Dutch 1954 statute redefining Suriname and the Dutch Antillean islands as part of the Kingdom of the Netherlands all demonstrate the tenacity of imperial priorities and mentalities (Aldrich and Connell 1992; Murphy 2018; Oostindie and Klinkers 2003; Thompson 2012; Ward, forthcoming). Post-war European empires' survival into and often beyond the 1970s despite the intervening spate of decolonizations culminating in the early 1960s, moreover, renders Europe's global imperial histories not simply 
durable national ones that, in their waning years, extended national citizenship to many colonized peoples across racial and geographical lines (Cooper 2014). As this chapter revisits in its conclusion, they also rendered the postwar European integration process as inseparable from empire, decolonization, and postcolonial dynamics as was the case for many individual member states in the future European Union.

Yet being part of imperial (and ultimately postcolonial) Europe did not require having held territory on other continents. Alongside Britain's informal empire comprised of vast regions across the globe that fell under its tremendous economic, political, and military sway can be placed imperial Germany's web of intercontinental engagements in Latin America, China, and other regions that greatly exceeded its 30-year era of formal colonialism in Africa and the Pacific between the mid-1880s and the First World War (Conrad 2010; Naranch and Eley 2014). Relatedly, scholars now frame Switzerland-long all but excluded from the 'imperial turn'-as a country that engaged in 'colonialism without colonies'. It counted among the societies that 'had an explicit self-understanding as being outside the realm of colonialism, but nevertheless engaged in the colonial project in a variety of ways and benefitted from these interactions' (Lüthi et al. 2016, 1; Purtschert and Fischer-Tiné 2015). Like other Europeans, the Swiss derived economic advantages from other countries' colonies and utilized shared notions of white supremacy that became apparent within their popular culture, fine arts, academic discourse, and understandings of national identity. Individuals' involvement in other powers' colonial projects as explorers, missionaries, scientists, emigrants, and travellers; profitable trade and overseas investments; colonial commodities and artistic and literary cultures; racial understandings of their majority populations as 'European', 'white', 'civilized', and 'superior' when contrasted with black, Asian, and Middle Eastern 'others': all count among the ways that Europeans across national lines could become complicit and enmeshed in the colonial endeavour. This worked to their own considerable advantage, whether they hailed from London, Paris, Antwerp, Lisbon, Berlin, or Zürich, or, for that matter, from Stockholm, Copenhagen, and other points further north.

\section{Imperializing Nordic Europe}

Scandinavia too has typically been all but absent from most understandings and academic analyses of modern European empires and colonial engagements, and with far less justification than Switzerland (Höglund and Burnett 2019). Denmark, for instance, may well have shrunk drastically in terms of land and power since the seventeenth century, but it nevertheless qualified as an imperial kingdom long afterwards. Most familiar is its severe contraction within Europe upon forfeiting a series of territories to Sweden since the mid1600s (including Norway in 1814) and to Germany in 1864. Less widely known are the small territories Denmark once claimed in India, West Africa, 
and the West Indies before selling the first two to the British in the 1840s and the third to the United States in 1917. Like other European countries with overseas dimensions, Danish imperial history also extended to involvement in the transatlantic slave trade and Caribbean slaveholding together with many other empowered forms of interaction with the 'tropics' (Adler-Nissen and Gad 2014; Andersen 2013; Jensen 2018; Olwig 2003).

Denmark's withdrawals thus significantly pre-dated many other European departures from overseas domains, but only if attention is restricted to its formal hold over parts of the Global South. Looking towards the Global North, by contrast, tells a far more complicated and extended story, one that remains underrepresented within colonial and postcolonial studies despite the gradual emergence of a stimulating body of specialist work. Denmark's expansive extra-European history in the North Atlantic and Arctic region dated from the time of the Vikings, continuing until and beyond the midtwentieth century period that rendered decolonization a global, trans-imperial phenomenon. Danish colonialism in Iceland lasted until the Second World War and even longer elsewhere. In precisely the same early post-war years that saw France and Portugal proclaim their colonies to be 'overseas provinces' and the Netherlands redefine itself as encompassing its territories across the Atlantic, Denmark behaved comparably, bringing extra-European holdings into the nation itself. Greenland, with its native Inuit population, stopped being what was effectively a colony in 1953, not because it achieved independence but because, like the Faroe Islands, it was incorporated within the Danish kingdom. Denmark did this for much the same reason as other European empires - to justify the state's ongoing claims over lands that the United Nations deemed ripe for decolonization by announcing that they were no longer colonies at all and to stymie demands for self-determination. Having only achieved home rule in 1979 and self-governing status in 2009, Greenland still lacks full sovereign status outside the Danish rubric, thus qualifying - albeit rarely understood - as a case of incomplete decolonization to this day (Gad 2014; Jensen 2018, Chapter 4).

Nor was Denmark the only Northern European state engaged with imperial processes more commonly associated with other parts of the continent. Sweden's early modern expansionism extended to Baltic annexations as well as the acquisition of overseas outposts in the seventeenth century, including New Sweden in North America, the Caribbean island of Saint Barthélemy, and several trading posts in Africa. That it did not expand further was not through want of trying, only of success. Sweden had its own Africa Company and East India Company just as Britain and the Netherlands did, but unlike the latter its ambitions largely remained unfulfilled, with its non-European territories rapidly turned over to other competing powers. In the early nineteenth century it also lost Finland to the Russian empire yet gained Norway from Denmark, holding it until Norway gained independence in 1905. Whether Sweden's rule over Finland, and later Norway, was tantamount to a colonial project in terms of its manner of administration and subjugation of 
local populations remains, unsurprisingly, a matter for debate (Fur 2013, 22; Neumann 2014, 126-7).

Denmark and Sweden may thus have ranked as minor imperial powers at best on the global stage, yet imperial powers they were nonetheless, even if on a smaller scale or for a shorter time than was the case for Britain, Portugal, or other examples noted above. Like the Swiss, moreover, Scandinavian colonial activities went significantly beyond any formal state-level territorial holdings and entailed multiple forms of involvement in other European countries' overseas projects (Brimnes et al. 2009). Whether as sailors, explorers, scientists, missionaries, traders, investors, or emigrating settlers or through access to colonial commodities, literature, and art forms, Northern Europeans also could make use of the material opportunities and selfaggrandizing racial understandings that circulated and embedded themselves transnationally (and transimperially) across European borders. Regardless of whether they belonged to states that formally possessed their own colonies across oceans or whether their own homelands could plausibly be described as colonies themselves within Northern Europe, they long remained active agents and beneficiaries of global imperial projects (Engh 2009).

Finally, in a manner comparable to the Irish within the British empire, Norwegians and Finns potentially count among the Europeans who qualified as being colonized at home yet played colonizing roles on imperial stages located further afield. Nor did the Finns' history of racialization within Europe - of having long been classified as of 'Mongol' or 'Asiatic' descent, and less 'white' than other Europeans - prevent them from engaging in forms of internal colonialism within their own borders after achieving independence from the collapsing Russian empire in 1917 (Keskinen 2019). Together with Sweden as well as Norway since its own independence, Finland's treatment of the indigenous Sámi peoples spread across borders in Scandinavia's far North involved racial discrimination, a 'civilizing mission', land expropriation, and exploitation of natural resources. Long considered 'backward' candidates for 'improvement', positioning the Sámi vis-à-vis other subaltern colonized groups remains all too rare within colonial and postcolonial scholarship beyond specialist regional studies (Fur 2013, 23; Lehtola 2015; also see other chapters in Loftsdóttir and Jensen 2012; Naum and Nordin 2013).

\section{Central and Eastern Europe's imperial turns}

Modern Germany, noted briefly above, offers examples of both short-lived overseas colonialism in Africa and the Pacific that was terminated by its First World War defeat as well as a more lengthy history of encounters with Eastern Europe, particularly Poland. Many historians now argue the latter to have been tantamount to colonial power relations, not least given widespread German understandings of Eastern European ethnic groups as racially inferior. The tragic consequences of these outlooks culminated when much of the region fell under Nazi occupation and suffered from its racist and 
genocidal policies. The Third Reich's targeting of Eastern European spaces for conquest and settlement and of Jews, 'Slavs', and other groups for merciless suppression, removal, or outright annihilation extended from longer histories of regional domination. Yet they also drew upon widely shared European colonial mentalities and behaviours recurrent on other continents, not exclusively from Germany's own history of genocidal war in early twentieth-century South-West Africa (Conrad 2010, 2013; Mazower 2009; Zimmerer 2011). The entanglement of Nazi occupations and the Holocaust within Europe with colonial oppression and violence outside Europe was set to continue into the age of decolonization, with memories of atrocities under Hitler informing international responses to European brutality while combatting anti-colonial insurgencies in French Algeria and other theatres of conflict in Asia and Africa after 1945 (Rothberg 2009).

Nazi expansionism, however, first began with its Anschluß (annexation) of Austria in 1938. As Hitler's forces entered Vienna that March, they assumed control over the short-lived republic that was a shrunken remnant of the Habsburg empire that had survived for over half a millennium before being brought down at the end of the First World War. After 1918, Vienna's urban landscape was that of a post-imperial capital whose grandiose architecture better reflected the multinational Austro-Hungarian empire of yesteryear that claimed over 50 million subjects, not the small and unstable Alpine republic it had become.

Historians have now begun re-examining the Habsburg monarchy's territories and structure as an empire, as opposed to focusing on ethnic nationalisms and the new nation-states that succeeded it (Judson 2016; Kumar 2017). Even so, few studies move past Austria-Hungary as a continental empire to situate it within wider global and maritime imperial histories. Yet the dynasty had once encompassed both Austrian and Spanish branches that saw Habsburgs ruling Spain alongside its vast territories in the New World until the early eighteenth century. When Spain and Spanish America passed into French royal hands, the Habsburgs consolidated their realm within Central Europe and expanded further east. Alongside Prussia and Russia, it took part in the 1795 partition of Poland after having acquired Galicia and Bukovina. The latter were widely conceived at the imperial centre as backward, primitive, misgoverned, and in dire need of 'civilization' via more enlightened Habsburg rule. As Pieter Judson underscores, the dynasty deployed 'the imperialist language of Western superiority articulated by proponents of global colonialism' (Judson 2016, 74; see also Feichtinger et al. 2003).

Come the nineteenth century, moreover, the Habsburg empire was not merely an inland Donaumonarchie (Danube monarchy) (Johler 1999, 88); it gained an increasingly prominent maritime presence in the Adriatic and Mediterranean, with Trieste counting as one of the world's ten largest port cities and Austria-Hungary's gateway to the sea. The Austrian Lloyd shipping company's trans-Mediterranean trade encompassed material goods and 'free' passengers as well as slaves transported between Ottoman and other 
ports (Frank 2012). Austria-Hungary too thus counted among Europe's Mediterranean powers, albeit in a different way than France, Britain, Spain, or Italy with their hold over North African colonies, protectorates, and enclaves. As other European empires encroached further into Asia or competed in the 'Scramble for Africa', Austria-Hungary also viewed the global stage as important to its prosperity and its international standing as a Great Power, albeit a second-tier one. Its failure to take formal control of territory on other continents did not reflect a lack of interest in or a rejection of imperial projects; instead, it participated enthusiastically and profitably in global commerce. Alison Frank's research provides a much-needed reminder that an informal empire revolving around trade, shipping, and other activities characterized not just modern Britain or Germany, as noted above, but also described states like Austria-Hungary which are still more commonly remembered (and studied) as strictly 'continental' (Frank 2011).

Habsburg formal territorial expansionism in the age of high imperialism, meanwhile, involved acquisitions to its south and east that were tantamount to an internal colonialism centred on the Balkans. By the 1870s, AustriaHungary entered a new phase of its struggle for land and influence against the Ottoman empire whose borders it shared. The 'Turkish threat' and the fight against the 'infidel' going back to the 1500s and 1600s (when Hungary itself fell under Ottoman rule for a century and a half) morphed into modern tensions pervading Ottoman relations with other European powers. Whether against Britain and France as their empires absorbed Ottoman territories in North Africa or against the Habsburg and Romanov Russian empires in Eastern and Southeastern Europe, the Ottomans' geographical reach contracted from the late eighteenth century onwards. Some areas like Greece, Serbia, Romania, and Bulgaria became autonomous or independent with foreign backing, but successive Ottoman losses were largely other European empires' gains. Austria-Hungary's 1878 occupation of Bosnia-Herzegovina (and ultimately its annexation 30 years later) had all the trappings of a colonial project replete with a 'civilizing mission' - directed not least at its substantial Muslim population - meant to legitimize its control and governance, albeit an adjacent European colonial project as opposed to a distant overseas one (Judson 2016, 330).

Both within and beyond the continent, the Ottoman empire's status as the 'sick man of Europe' eroded ever further as it steadily receded from Europe and grew increasingly Islamic (as opposed to encompassing peoples of many faiths, most prominently Eastern Orthodox Christians and Jews, as it had before). While it was the locus of Western 'Orientalism' so influentially explored by Edward Said and acted as 'the classic "other" of Western civilization' (Kumar 2017, 76; Said 1978), the Ottoman empire was in fact long a decidedly European one at the same time as it straddled continents and was situated at Europe's ambiguous borders with the 'Oriental' world. 'It is indeed possible to stress the non-European-Turkic, Arabic, Persian-aspects of the Ottoman Empire', Krishan Kumar writes. 'Yet properly considered it has 
at least as much claim to be thought European as, say, the Russian Empire' in terms of its geographical expanse, not to mention its centuries-long impact across much of the continent (Kumar 2017, 79). Like much else, its demise alongside Europe's other empires comprising the defeated Central Powers of the First World War attested to its entanglement with broader European trajectories until the end.

Europe's 'Orient' and colonial activities, as such, crucially lay beyond yet simultaneously within itself, most prominently the further east and southeast a more 'Western'-situated gaze extended. Indeed, Europe's Orients were at once overlapping and plural, with their geographical, cultural, and often racialized delineations historically in flux. The dividing line between East and West recurrently proved as frustratingly vague as it was intangible, perhaps most vividly in Europe's own contiguous Easts like the Balkans and Russia. Both have been widely imagined as European 'peripheries' (and often not 'properly European') or as crossroads between Europe and Asia, or Europe and its Near or Middle East (Bakić-Hayden and Hayden 1992).

If the Balkans have commonly been construed as 'semideveloped, semicolonial, semicivilized, semioriental', as Maria Todorova has influentially explored (Todorova 2009, 16), in Alexander Etkind's interpretation the Romanov empire of Russia (1613-1917) counted as both an outwardly expanding Eurasian power and one that 'constituted itself through the process of colonization', thereby being 'created by the process it performed' (Etkind 2011, 67-8). Through state-organized (often forced) migrations akin to colonization by settlers as well as the naturalization of hierarchical cultural, legal, and class distinctions subdividing its own population-for example, between masters and serfs - the Russian empire 'colonized its own people'. 'Defining its others by estate and religion' just as 'Western empires defined them by geography and race', Russian colonial acts and mentalities extended both across its own heartland as internal colonization and outwards to Eastern Europe, the Middle East, Central Asia, and the Pacific. In this sense, Russia was 'both the subject and the object of orientalism' (Etkind 2011, 251-2; see also Kemper 2018).

That the Tsarist empire grew until it stretched from the Arctic to the Black Sea and from the Baltic to the Pacific (and once extended as far as California and Alaska) underscores the importance of its sea borders and maritime dimensions, thereby complicating its portrayals as primarily a land empire. Its intercontinental and global reach brought it into collision not only with the Habsburgs and Ottomans but with the Japanese, Chinese, and the British overseas empire, the latter as Britain moved beyond British India further north into Afghanistan and played a decades-long Central Asian 'Great Game' against Russian competitors for regional influence. Russia was a Eurasian empire as well as a European power, with the former in fact making the latter possible. As Mark Smith has summarized, '[i]ts expansionary identity was precisely what made it a great power like Britain and France, and even what defined its European status' (Smith 2019, 256; see also Kivelson 
and Suny 2017; Lieven 2002). Russia's integrated history of European and extra-European modern imperialisms up to the Romanov empire's termination by the Russian Revolution was followed by the Soviet Union's multiple engagements with its constituent multinational republics, nearest neighbours, and the wider world alike (Martin 2001).

Examining Eastern Europe through a colonial and postcolonial prism has allowed scholars including James Mark and Quinn Slobodian to propose that the region qualifies as 'the first site of decolonization in the twentieth century' as new nation-states emerged with the dissection of the Habsburg and Tsarist empires after the First World War (Mark and Slobodian 2018, 352; see also Gerwarth 2017, Chapter 11). Its rapid occupation by Nazi Germany and the Soviet Union during the Second World War, followed by its subordination within the Eastern bloc dominated by the Soviet 'evil empire' throughout the Cold War, entailed further phases of intra-European colonization as 'the West's original Third World, its nearest quasi-oriental space', as David Chioni Moore has put it $(2001,122)$. At the same time, however, it actively participated in a variety of 'Second World' socialist engagements with Asia, Africa, and Latin America via ideological solidarities and material interconnections as the 'Third World' struggled against colonialism and neo-colonial arrangements. As such, Europe's East as well as its 'First World' West were both connected with wider global transitions as overseas empires formally drew to a close, up until the Soviet empire's own disintegration between 1989 and 1991 (Mark, Iacob et al. 2019, Mark, Kalinovsky et al. 2020).

\section{From decolonization to Europe's integration and postcolonial condition}

Studying Central-Eastern Europe since 1989 as simultaneously post-socialist and postcolonial is only one way that Europe's shared colonial history and current shared postcolonial condition becomes apparent (Głowacka-Grajper 2018). As this chapter has outlined, European states and empires 'at home' were mutually constituted by manifold interactions with the wider world. These ties did much to make Europe what it was, whether in material, geopolitical, or cultural terms, and most certainly in terms of dominant racial selfidentifications. Moreover, the gradual winding-down of overseas empires after 1945 occurred in tandem with Europe's increasing integration as it evolved during and after the 1950s.

Bringing Europe's imperial and decolonization histories together with the European Union's history since the birth of the European Economic Community in 1957 remains, to date, a move made in all too few academic treatments (with Hansen and Jonsson 2014, Patel 2020 and Pasture 2018 being prominent among them). Yet the EEC and later EU's inseparability from overseas empires and their histories, if largely unacknowledged, was just as pronounced as that of many of its member states that either still held colonies and other overseas territories or had recently relinquished them 
when they joined (Bhambra 2009; Fisher Onar and Nicolaïdis 2013; Ward and Rasch 2019). This explains why Algeria (which France insisted was part of itself) was once part of the EEC until its independence, as was Greenland (as part of Denmark) until the late 1970s; it also accounts for the EU's current geographical expansiveness far beyond continental Europe through its many 'Overseas Countries and Territories' and 'Outermost Regions'. Scattered outposts extend the EU's reach into the Caribbean, South America, and the Indian Ocean (including the Dutch Antilles and French overseas départements and territories that still comprise parts of these nations themselves), into the Atlantic and Pacific, and to the Spanish enclaves of Ceuta and Melilla across the Mediterranean in Northern Africa.

As such, like Europe, the EU is still not fully postcolonial in the present day, yet its population nevertheless testifies to the deep impact of colonial legacies and the unfinished business of empire. Ever since overseas empires began their post-war retreat, rising numbers of (ex-) colonial peoples arrived to ultimately render significant parts of the continent ever more multicultural and ethnically diverse (see Buettner 2016, 2018a, 2018b, and 2020, which discuss a far wider range of scholarship). Insisting on empire and colonialism as shared, if highly differentiated, European experiences goes hand in hand with recognizing the Europeanness of Europe's millions of ethnic minorities in the wake of decolonization. While they often arrived as citizens of late-imperial and recently imperial nation-states, many minorities from Asia, Africa, the Middle East, and the Caribbean suffered from social exclusion and found it difficult to gain acceptance, either as legitimate members of European nations or as 'European' more generally, on account of their allegedly 'racial', cultural, and religious differences from the majority. As Stuart Hall put it, they may have been 'in' Europe, yet were often not recognized as genuinely 'of' Europe (Hall 2003), despite being a transnational presence and a central part of Europe's 'identity', whether openly acknowledged or not (see also Balibar 2004, 223). The European Union's much-lauded aspiration to embody 'Unity in Diversity', as its motto celebrates, demands that greater attention be paid not only to national diversity but to its multicultural diversity that longstanding colonial entanglements have made an irrevocable part of postcolonial EUrope.

The EU's diversity also describes its current member states that have very different relationships with the colonial past. After multiple expansions, it has grown to include both ex-colonizing nations and those once tantamount to having been colonized themselves by their neighbours, whether they be Ireland or the series of post-socialist Central and Eastern European countries that have acceded since 2004. Within an EU that places a high priority upon internal freedom of movement at the same time as defending its external borders from unwanted migrants, intra-EU migrants from these countries have often found themselves racialized when they reached their destinations, albeit as whites and in distinction from those whose ancestral roots lay outside the continent (Fox 2013; Mark, Iacob et al. 2019, Chapter 
3; McDowell 2009; Zahra 2016, Chapter 7 and postscript). Together with its 'inner East' (Ballinger 2017, 51), the EU is geographically, culturally, and symbolically defined by its most proximate 'others' across the Mediterranean and just beyond its eastern and southeastern land borders, particularly Russia, parts of the former Yugoslavia whose heritage is more Ottoman than Habsburg, and Turkey (Bakić-Hayden 1995; Neumann 1999; Risse 2010). These multiple 'Orients', including many characterized as mainly Islamic, qualify as EU 'neighbours' at best as distinct from viable candidates for future membership (Kølvraa 2017; Kuus 2004). Understanding EUrope's colonial heritage requires that attention be paid to how these 'others'-some already located within itself, some located just beyond its borders-have defined European identities, both historically and today.

\section{Note}

1 This work forms part of the ECHOES project which has received funding from the European Union's Horizon 2020 research and innovation programme under grant agreement No. 770248. It partly draws on Elizabeth Buettner. 2018. 'European Entanglements'. ECHOES: European Colonial Heritage Modalities in Entangled Cities. https://keywordsechoes.com/european-entanglements.

\section{References}

Adler-Nissen, Rebecca, and Ulrik P. Gad. 2014. "Introduction: Postimperial Sovereignty Games in the Nordic Region.” Cooperation and Conflict 49 (1): 3-32.

Aldrich, Robert, and John Connell. 1992. France's Overseas Frontier: Départements et Territoires d'Outre-Mer. Cambridge: Cambridge University Press.

Andersen, Astrid Nonbo. 2013. "We Have Reconquered the Islands': Figurations in Public Memories of Slavery and Colonialism in Denmark 1948-2012." International Journal of Politics, Culture, and Society 26 (1): 57-76.

Anderson, Benedict. 2006 (revised edition). Imagined Communities: Reflections on the Origin and Spread of Nationalism. London: Verso.

Bakić-Hayden, Milica. 1995. "Nesting Orientalisms: The Case of Former Yugoslavia.” Slavic Review 54 (4): 917-31.

Bakić-Hayden, Milica, and Robert M. Hayden. 1992. "Orientalist Variations on the Theme 'Balkans': Symbolic Geography in Recent Yugoslav Cultural Politics." Slavic Review 51 (1): 1-15.

Balibar, Étienne. 2004. We, the People of Europe? Reflections on Transnational Citizenship. Translated by James Swenson. Princeton: Princeton University Press.

Ballinger, Pamela. 2017. "Whatever Happened to Eastern Europe? Revisiting Europe's Eastern Peripheries." East European Politics and Societies and Cultures 31 (1): 44-67.

Bethencourt, Francisco, and Diogo Ramada Curto, eds. 2007. Portuguese Oceanic Expansion, 1400-1800. Cambridge: Cambridge University Press.

Bhambra, Gurminder K. 2009. "Postcolonial Europe, or Understanding Europe in Times of the Postcolonial." In The Sage Handbook of European Studies, edited by Chris Rumford, 69-85. London: Sage. 
Blanchard, Pascal, Sandrine Lemaire, and Nicolas Bancel, eds. 2008. Culture coloniale en France: De la Révolution à nos jours. Paris: CNRS Éditions.

Borutta, Manuel, and Sakis Gekas. 2012. "A Colonial Sea: The Mediterranean, 17981956.” European Review of History — Revue européenne d'histoire 19 (1): 1-13.

Brimnes, Niels, Pernille Ipsen, and Gunvor Simonsen, eds. 2009. "Scandinavian Colonialism." Special issue, Itinerario. 33 (2). https://www.cambridge.org/core/ journals/itinerario/issue/8AD3938B20096E67D560BF6609FF40BD.

Bruendel, Steffen. 2017. "Challenging British Sovereignty: Transnational Activism and Political Power in Northern Ireland, 1963-1973." In The Global 1960s: Convention, Contest and Counterculture, edited by Tamara Chaplin and Jadwiga E. Pieper Mooney, 72-95. London: Routledge.

Buettner, Elizabeth. 2016. Europe after Empire: Decolonization, Society, and Culture. Cambridge: Cambridge University Press.

Buettner, Elizabeth. 2018a. "Postcolonial Migrations to Europe." In The Oxford Handbook of the Ends of Empire, edited by Martin Thomas and Andrew S. Thompson, 601-20. Oxford: Oxford University Press.

Buettner, Elizabeth. 2018b. "What - and Who - is 'European' in the Postcolonial EU? Inclusions and Exclusions in the European Parliament's House of European History." BMGN-Low Countries Historical Review 133 (4): 132-48.

Buettner, Elizabeth. 2020. "Europeanising Migration in Multicultural Spain and Portugal during and after the Decolonisation Era." Itinerario 44 (1): 159-77.

Burbank, Jane, and Frederick Cooper. 2010. Empires in World History: Power and the Politics of Difference. Princeton: Princeton University Press.

Burton, Antoinette, ed. 2003. After the Imperial Turn: Thinking with and through the Nation. Durham: Duke University Press.

Conklin, Alice L., Sarah Fishman, and Robert Zaretsky. 2011. France and Its Empire since 1870: The Republican Tradition. New York: Oxford University Press.

Conrad, Sebastian. 2010. Globalisation and the Nation in Imperial Germany. Translated by Sorcha O'Hagan. Cambridge: Cambridge University Press.

Conrad, Sebastian. 2013. "Rethinking German Colonialism in a Global Age." Journal of Imperial and Commonwealth History 41 (4): 543-66.

Cooper, Frederick. 2014. Citizenship between Empire and Nation: Remaking France and French Africa, 1945-1960. Princeton: Princeton University Press.

Engh, Sunniva. 2009. "The Conscience of the World? Swedish and Norwegian Provision of Development Aid.” Itinerario 33 (2): 65-82.

Etkind, Alexander. 2011. Internal Colonization: Russia's Imperial Experience. Cambridge: Polity Press.

Feichtinger, Johannes, Ursula Prutsch, and Moritz Csáky, eds. 2003. Habsburg postcolonial: Machtstrukturen und kollectives Gedächtnis. Innsbruck: Studien Verlag.

Fisher Onar, Nora, and Kalypso Nicolaïdis. 2013. "The Decentring Agenda: Europe as a Post-Colonial Power." Cooperation and Conflict 48 (2): 283-303.

Fox, Jon E. 2013. "The Uses of Racism: Whitewashing New Europeans in the UK." Ethnic and Racial Studies 36 (11): 1871-89.

Frank, Alison. 2011. "Continental and Maritime Empires in an Age of Global Commerce." East European Politics and Society 25 (4): 779-84.

Frank, Alison. 2012. "The Children of the Desert and the Laws of the Sea: Austria, Great Britain, the Ottoman Empire, and the Mediterranean Slave Trade in the Nineteenth Century." American Historical Review 117 (2): 410-44. 
Fur, Gunlög. 2013. "Colonialism and Swedish History: Unthinkable Connections?" In Scandinavian Colonialism and the Rise of Modernity: Small Time Agents in a Global Arena, edited by Magdalena Naum and Jonas M. Nordin, 17-36. New York: Springer.

Gad, Ulrik P. 2014. "Greenland: A Post-Danish Sovereign Nation State in the Making." Cooperation and Conflict 49 (1): 98-118.

Gerwarth, Robert. 2017. The Vanquished: Why the First World War Failed to End, 1917-1923. London: Penguin.

Głowacka-Grajper, Małgorzata. 2018. "Internal Colonisation.” ECHOES: European Colonial Heritage Modalities in Entangled Cities. Accessed 13 June 2020. https:// keywordsechoes.com/internal-colonisation.

Goddeeris, Idesbald. 2015. "Postcolonial Belgium: The Memory of the Congo." Interventions: International Journal of Postcolonial Studies 17 (3): 434-51.

Goddeeris, Idesbald, Amandine Lauro and Guy Vanthemsche, eds. 2020. Koloniaal Congo: een geschiedenis in vragen. Kalmthout: Polis/Pelckmans.

Hall, Catherine, and Sonya O. Rose, eds. 2006. At Home with the Empire: Metropolitan Culture and the Imperial World. Cambridge: Cambridge University Press.

Hall, Stuart. 2003. "In But Not Of Europe.” In Figures d'Europe: Images and Myths of Europe, edited by Luisa Passerini, 35-46. Brussels: P.I.E.-Peter Lang.

Hansen, Peo, and Stefan Jonsson. 2014. Eurafrica: The Untold History of European Integration and Colonialism. London: Bloomsbury.

Hechter, Michael. 1978. Internal Colonialism: The Celtic Fringe in British National Development, 1536-1966. London: Routledge and Kegan Paul.

Höglund, Johan, and Linda Andersson Burnett, eds. 2019. "Nordic Colonialisms." Special issue, Scandinavian Studies 91 (1-2): 1-268. Champaign, Illinois: University of Illinois Press.

Howe, Stephen. 2000. Ireland and Empire: Colonial Legacies in Irish History and Culture. Oxford: Oxford University Press.

Jensen, Lars. 2018. Postcolonial Denmark: Nation Narration in a Crisis Ridden Europe. London: Routledge

Jerónimo, Miguel Bandeira, and António Costa Pinto, eds. 2013. "International Dimensions of Portuguese Late Colonialism and Decolonization." Special issue, Portuguese Studies 29 (2). Cambridge, UK: Modern Humanities Research Association. https://www.jstor.org/stable/10.5699/portstudies.29.issue-2

Johler, Reinhard. 1999. "A Local Construction-Or: What Have the Alps To Do With a Global Reading of the Mediterranean?” Narodna Umjetnost 36 (1): 87-102.

Judson, Pieter M. 2016. The Habsburg Empire: A New History. Cambridge: Harvard University Press.

Kemper, Michael. 2018. "Russian Orientalism.” In Oxford Research Encyclopedias: Asian History, edited by David Ludden. Oxford: Oxford University Press. Accessed 30 August 2020. https://oxfordre.com/asianhistory/view/10.1093/acrefore/ 9780190277727.001.0001/acrefore-9780190277727-e-297.

Kennedy, Dane. 2018. The Imperial History Wars: Debating the British Empire. London: Bloomsbury.

Kenny, Kevin, ed. 2004. Ireland and the British Empire (Oxford History of the British Empire Companion Series). Oxford: Oxford University Press.

Keskinen, Suvi. 2019. "Intra-Nordic Differences, Colonial/Racial Histories, and National Narratives: Rewriting Finnish History." Scandinavian Studies 92 (1-2): 163-81. 
Kivelson, Valerie A., and Ronald Grigor Suny. 2017. Russia's Empires. Oxford: Oxford University Press.

Koekkoek, René, Anne-Isabelle Richard, and Arthur Weststeijn. 2017. "Visions of Dutch Empire: Towards a Long-Term Global Perspective.” BMGN_Low Countries Historical Review 132 (2): 79-96.

Kølvraa, Christoffer. 2017. "Limits of Attraction: The EU's Eastern Border and the European Neighbourhood Policy." East European Politics and Societies and Cultures 31 (1): 11-25.

Kumar, Krishan. 2017. Visions of Empire: How Five Imperial Regimes Shaped the World. Princeton: Princeton University Press.

Kuus, Merje. 2004. "Europe's Eastern Expansion and the Reinscription of Otherness in East-Central Europe.” Progress in Human Geography 28 (4): 472-89.

Laird, Heather. 2015. "European Postcolonial Studies and Ireland: Towards a Conversation amongst the Colonized of Europe." Postcolonial Studies 18 (4): 384-96.

Lehtola, Veli-Pekka. 2015. "Sámi Histories, Colonialism, and Finland." Arctic Anthropology 52 (2): 22-36.

Leonhard, Jörn. 2016. "Comparison, Transfer and Entanglement, or: How to Write Modern European History Today?” Journal of Modern European History 14 (2): 149-63.

Lieven, Dominic. 2002. Empire: The Russian Empire and Its Rivals. New Haven: Yale University Press.

Loftsdóttir, Kristín, and Lars Jensen, eds. 2012. Whiteness and Postcolonialism in the Nordic Region: Exceptionalism, Migrant Others, and National Identities. London: Routledge.

Lombardi-Diop, Cristina, and Caterina Romeo. 2015a. "Italy's Postcolonial 'Question': Views from the Southern Frontier of Europe." Postcolonial Studies 18 (4): 367-83.

Lombardi-Diop, Cristina, and Caterina Romeo, eds. 2015b. "Postcolonial Europe." Special issue, Postcolonial Studies 18 (4). London: Routledge/Taylor \& Francis Group

Lüthi, Barbara, Francesca Falk, and Patricia Purtschert, eds. 2016. "Colonialism without Colonies: Examining the Blank Spaces in Colonial Studies." Special issue, National Identities 18 (1). London: Routledge/Taylor \& Francis Group

MacKenzie, John M., ed. 1986. Imperialism and Popular Culture. Manchester: Manchester University Press.

MacKenzie, John M., ed. 2011. European Empires and the People: Popular Responses to Imperialism in France, Britain, the Netherlands, Belgium, Germany and Italy. Manchester: Manchester University Press.

MacKenzie, John M., and T.M. Devine, eds. 2011. Scotland and the British Empire (Oxford History of the British Empire Companion Series). Oxford: Oxford University Press.

Mark, James, Bogdan C. Iacob, Tobias Rupprecht, and Ljubica Spaskovska. 2019. 1989: A Global History of Eastern Europe. Cambridge: Cambridge University Press.

Mark, James, Artemy Kalinovsky, and Steffi Marung, eds. 2020. Alternative Globalizations: Eastern Europe and the Postcolonial World. Bloomington: Indiana University Press. 
Mark, James, and Quinn Slobodian. 2018. "Eastern Europe in the Global History of Decolonization." In The Oxford Handbook of the Ends of Empire, edited by Martin Thomas and Andrew S. Thompson, 351-72. Oxford: Oxford University Press.

Martin, Terry. 2001. The Affirmative Action Empire: Nations and Nationalism in the Soviet Union, 1923-1939. Ithaca: Cornell University Press.

Mazower, Mark. 2009. Hitler's Empire: Nazi Rule in Occupied Europe. London: Penguin.

McDonough, Terrence, ed. 2005. Was Ireland a Colony?: Economics, Politics and Culture in Nineteenth-Century Ireland. Dublin: Irish Academic Press.

McDowell, Linda. 2009. "Old and New European Economic Migrants: Whiteness and Managed Migration Policies.” Journal of Ethnic and Migration Studies 35 (1): 19-36.

Moore, David Chioni. 2001. "Is the Post- in Postcolonial the Post- in Post-Soviet? Toward a Global Postcolonial Critique." PMLA 116 (1): 111-28.

Murphy, Philip. 2018. The Empire's New Clothes: The Myth of the Commonwealth. London: Hurst.

Naranch, Bradley, and Geoff Eley, eds. 2014. German Colonialism in a Global Age. Durham: Duke University Press.

Naum, Magdalena, and Jonas M. Nordin, eds. 2013. Scandinavian Colonialism and the Rise of Modernity: Small Time Agents in a Global Arena. New York: Springer.

Neumann, Iver B. 1999. Uses of the Other: 'The East' in European Identity Formation. Minneapolis: University of Minnesota Press.

Neumann, Iver B. 2014. "Imperializing Norden." Cooperation and Conflict 49 (1): 119-29.

Olwig, Karen Fog. 2003. "Narrating Deglobalization: Danish Perceptions of a Lost Empire." Global Networks 3 (3): 207-22.

Oostindie, Gert, and Inge Klinkers. 2003. Decolonising the Caribbean: Dutch Policies in a Comparative Perspective. Amsterdam: Amsterdam University Press.

Osterhammel, Jürgen. 2014. The Transformation of the World: A Global History of the Nineteenth Century. Translated by Patrick Camiller. Princeton: Princeton University Press.

Pasture, Patrick. 2018. "The EC/EU between the Art of Forgetting and the Palimpsest of Empire.” European Review 26 (3): 545-81.

Patel, Kiran Klaus. 2020. Project Europe: A History. Cambridge: Cambridge University Press.

Pergher, Roberta. 2017. Mussolini's Nation-Empire: Sovereignty and Settlement in Italy's Borderlands, 1922-1943. Cambridge: Cambridge University Press.

Purtschert, Patricia, and Harald Fischer-Tiné, eds. 2015. Colonial Switzerland: Rethinking Colonialism from the Margins. Basingstoke: Palgrave Macmillan.

Raben, Remco. 2013. "A New Dutch Imperial History?: Perambulations in a Prospective Field." BMGN-Low Countries Historical Review 128 (1): 5-30.

Risse, Thomas. 2010. A Community of Europeans? Transnational Identities and Public Spheres. Ithaca: Cornell University Press.

Rothberg, Michael. 2009. Multidirectional Memory: Remembering the Holocaust in the Age of Decolonization. Stanford: Stanford University Press.

Said, Edward W. 1978. Orientalism. New York: Pantheon.

Sanches, Manuela Ribeiro, ed. 2006. 'Portugal não é um país pequeno': Contar o 'império' na pós-colonialidade. Lisbon: Livros Cotovia. 
Santos, Boaventura de Sousa. 2002. "Between Prospero and Caliban: Colonialism, Postcolonialism, and Inter-identity." Luso-Brazilian Review 39 (2): 9-43.

Schilling, Britta. 2015. "German Postcolonialims in Four Dimensions: A Historical Perspective." Postcolonial Studies 18 (4): 427-39.

Shepard, Todd. 2006. The Invention of Decolonization: The Algerian War and the Remaking of France. Ithaca: Cornell University Press.

Sidaway, James D., and Marcus Power. 2005. "The Tears of Portugal': Empire, Identity, 'Race', and Destiny in Portuguese Geopolitical Narratives." Environment and Planning D: Society and Space 23 (4): 527-54.

Smith, Mark B. 2019. The Russia Anxiety and How History Can Resolve It. London: Penguin.

Stoler, Ann Laura, and Frederick Cooper. 1997. "Between Metropole and Colony: Rethinking a Research Agenda." In Tensions of Empire: Colonial Cultures in a Bourgeois World, edited by Ann Laura Stoler and Frederick Cooper, 1-56. Berkeley: University of California Press.

Stora, Benjamin. 1991. La gangrène et l'oubli: La mémoire de la guerre d'Algérie. Paris: Éditions La Découverte.

Stovall, Tyler. 2015. Transnational France: The Modern History of a Universal Nation. Boulder: Westview.

Subrahmanyam, Sanjay. 2007. "Holding the World in Balance: The Connected Histories of the Iberian Overseas Empires, 1500-1640." American Historical Review 112 (5): 1359-85.

Thomas, Martin, and Andrew S. Thompson, eds. 2018. The Oxford Handbook of the Ends of Empire. Oxford: Oxford University Press.

Thompson, Andrew S., ed. 2012. Britain's Experience of Empire in the Twentieth Century (Oxford History of the British Empire Companion Series). Oxford: Oxford University Press.

Todorova, Maria. 2009 (updated edition). Imagining the Balkans. Oxford: Oxford University Press.

Viaene, Vincent, David Van Reybrouck, and Bambi Ceuppens, eds. 2009. Congo in België: Koloniale cultuur in de metropool. Leuven: Universitaire Pers Leuven.

Von Hirschhausen, Ulrike, and Kiran Klaus Patel. 2010. "Europeanization in History: An Introduction." In Europeanization in the Twentieth Century: Historical Approaches, edited by Martin Conway and Kiran Klaus Patel, 1-18. Basingstoke: Palgrave Macmillan.

Ward, Stuart, ed. 2001. British Culture and the End of Empire. Manchester: Manchester University Press.

Ward, Stuart. Forthcoming. Untied Kingdom: A World History of the End of Britain. Cambridge: Cambridge University Press.

Ward, Stuart, and Astrid Rasch, eds. 2019. Embers of Empire in Brexit Britain. London: Bloomsbury.

Werner, Michael, and Bénédicte Zimmermann. 2006. "Beyond Comparison: Histoire Croisée and the Challenge of Reflexivity." History and Theory 45 (1): 30-50.

Weststeijn, Arthur. 2014. "The VOC as a Company-State: Debating SeventeenthCentury Dutch Colonial Expansion.” Itinerario 38 (1): 13-34.

Wilder, Gary. 2003. "Unthinking French History: Colonial Studies beyond National Identity." In After the Imperial Turn: Thinking with and through the Nation, edited by Antoinette Burton, 125-43. Durham: Duke University Press. 
Wilson, Kathleen, ed. 2004. A New Imperial History: Culture, Identity and Modernity in Britain and the Empire, 1660-1840. Cambridge: Cambridge University Press.

Zahra, Tara. 2016. The Great Departure: Mass Migration from Eastern Europe and the Making of the Free World. New York: W. W. Norton.

Zimmerer, Jürgen. 2011. Von Windhuk nach Auschwitz?: Beiträge zum Verhältnis von Kolonialismus und Holocaust. Berlin: Lit Verlag. 